\title{
Suitability of enterococcus faecalis as a test organism to evaluate in vivo efficacy of alcohol- based handrubs
}

\author{
RA Leslie ${ }^{1 *}$, DR Macinga ${ }^{1,2}$, FH Brill $^{3}$, M Suchomel $^{4}$ \\ From 3rd International Conference on Prevention and Infection Control (ICPIC 2015) \\ Geneva, Switzerland. 16-19 June 2015
}

\section{Introduction}

The World Health Organization has called for development of improved methods to evaluate efficacy of hand hygiene products that more closely reflect practical use patterns and have success criteria tied to clinical benefit. The test organisms should represent pathogens with environmental stability known for their potential to be spread by contaminated hands.

\section{Objectives}

Determine the suitability of a non-pathogenic Enterococcus faecalis strain as an alternative to Escherichia coli for in vivo efficacy evaluation of alcohol-based handrubs (ABHR).

\section{Methods}

Overall methodology based on European Norm 1500:2013. Test organisms were E. faecalis(ATCC 47077) or E. coli K12 (NCTC 10538). Hand contamination was performed by either the immersion method from EN 1500 or spreading $0.5 \mathrm{~mL}$ of a high titer suspension over all surfaces of both hands (based on ASTM E2755). Subjects performed a reference procedure according to EN 1500. Testing was conducted at two laboratories using E. faecalis and one facility using $E$. coli.

\section{Results}

Mean log prevalues (PV) for E. faecalis contamination by immersion were $6.56 \pm 0.27$ and $6.29 \pm 0.60$ and mean log reduction factors (RF) were $5.68 \pm 0.92$ and $4.63 \pm 0.26$, at the respective labs. Mean log PV for E. coli contamination by immersion was $5.38 \pm 0.55$ and mean $\log$ RF was

'Research and Development, GOJO Industries, USA

Full list of author information is available at the end of the article
4.61 \pm 0.74 . Mean log PVs for E. faecalis contamination by high titer were $5.78 \pm 0.40$ and $6.82 \pm 0.09$ and mean log RFs were $5.03 \pm 0.91$ and $5.16 \pm 0.56$, at the respective labs. Mean $\log$ PV for E. coli contamination by high titer was 4.76 \pm 0.52 and mean $\log$ RF was $3.86 \pm 0.95$. E. faecalis yielded PVs that exceeded E. coli PVs by $\sim 1-2$ log units using either mode of contamination suggesting greater survival during hand drying.

\section{Conclusion}

E. faecalis demonstrates strong potential as a test organism that represents a pathogen with high environmental stability known to be spread by contaminated hands in healthcare settings. Additionally, the low-volume contamination procedure is simpler to execute and more closely mimics the condition of hands when ABHR use is indicated in clinical settings (e.g. minimally soiled and fully dry). Further studies are needed to finalize the method and better understand the sensitivity of E. faecalis toalcohols to ensure it differentiates product performance similar to E. coli.

\section{Disclosure of interest}

None declared.

Authors' details

${ }^{1}$ Research and Development, GOJO Industries, USA. ${ }^{2}$ Northeastern Ohio Medical University, USA. ${ }^{3}$ Dr. Brill + Partner GmbH- Institute for Hygiene and Microbiology, Germany. ${ }^{4}$ Medical University Vienna, Austria.

Published: 16 June 2015

doi:10.1186/2047-2994-4-S1-P307

Cite this article as: Leslie et al: Suitability of enterococcus faecalis as a test organism to evaluate in vivo efficacy of alcohol-based handrubs. Antimicrobial Resistance and Infection Control 2015 4(Suppl 1):P307.
C Biomed Central

(c) 2015 Leslie et al; licensee BioMed Central Ltd. This is an Open Access article distributed under the terms of the Creative Commons Attribution License (http://creativecommons.org/licenses/by/4.0), which permits unrestricted use, distribution, and reproduction in any medium, provided the original work is properly cited. The Creative Commons Public Domain Dedication waiver (http:// creativecommons.org/publicdomain/zero/1.0/) applies to the data made available in this article, unless otherwise stated. 